Економічні науки: збірник наукових праць Луцького національного технічного університету. Серія "Регіональна економіка". Випуск 18 (71). Редкол.: відп. ред. д.е.н., професор Л.Л. Ковальська. Луцьк: ІВВ Луцького НТУ, 2021. 278 с.

УДК 338.43:34

Зелінська О.М., к.е.н., доцент

Іванішів В.

Луцький національний технічний університет

\title{
ОРГАНІЗАЦІЙНО-ЕКОНОМІЧНІ ОСНОВИ ФУНКЦІОНУВАННЯ СВІТОВОГО РИНКУ ЗЕРНА
}

Сьогодні в сучасній науковій літературі присутній ряд дослідницьких праць, пов'язаних з особливостями формування та функціонування світового ринку зерна. Ринок зерна відіграє вагому роль у забезпеченні світової продовольчої безпеки. У зв'язку $з$ цим, питання аналізу і системного концептуального осмислення організаційно-економічних основ та перспектив розвитку світового ринку зернових на сучасному етапі розвитку глобальної економіки $є$ різнорідними за своєю теоретико-методологічною основою: в науково-дослідному i експертному співтоваристві існують принципово неузгоджені теоретичні та практичні відмінності в підходах, що обумовлює необхідність в аргументації мети і завдань даного дослідження.

Ключові слова: світовий ринок зерна, вітчизняний ринок зерна, сільське господарство, зернові культури, посівна площа, експорт зерна.

\section{Zelinska O., Ivanishiv V.}

\section{ORGANIZATIONAL AND ECONOMIC BASIS OF FUNCTIONING OF THE WORLD GRAIN MARKET}

Today the world market of grain products remains one of the key and strategic vectors of domestic exports of agricultural products. Any changes or trends in this market have a direct impact on the state and dynamics of agricultural exports of Ukraine, as a country that is one of the key market players.In modern business conditions, this market is under the lens of constant monitoring. The results of these studies contain valuable information about market conditions, which is necessary for the development and adoption of management decisions.

The grain market is an open organizational and economic system through which economic entities realize their own economic interests in the field of exportimport of grain products. The studied market is endowed with the following characteristics: integrity, hierarchy and integration.Exploring the organizational and economic principles of the world market, it is important to study the laws and patterns, as the state of development of this market directly affects the development of related industries and industries. In addition, it should be recalled that grain is a key element of food security of any state. This explains the excessive interest of countries in their participation in this market.

The functioning of the world grain market can be reduced to the following goals:providing the population with basic necessities; providing grain related 
Економічні науки: збірник наукових прачь Луиького національного технічного університету. Серія “Регіональна економіка". Випуск 18 (71). Редкол.: відп. ред. д.е.н., професор Л.Л. Ковальська. Луцьк: ІВВ Луиького НТУ, 2021. 278 с.

industries; development of logistics directions from producers to end consumers; carrying out of daring works and realization of commodity interventions in the grain market; cultivation of export consignments of grain.

In the process of development of economic interaction between the subjects of the world grain market, the so-called integration models of producers and consumers of grain have been formed, which represent legally independent companies and various non-profit associations. Such relationships are formed as a result of joint production and marketing activities, mutual settlements, and so on.

In the process of studying the peculiarities of the principles of the world grain market, it should be noted that grain, as a guarantor of food security is also a source of wealth. In addition, grain is a commodity in both domestic and foreign markets, and the grain market is one of the most perfect and predictable in the world.

The main factors that can affect supply and demand in the grain market are the pricing policy of potential exporters, domestic prices, transitional stocks, the state's ability to carry out commodity interventions, the pricing policy of importing countries.

Given the fact that grain as a commodity is not expensive, so the profitability of its export will be slightly higher in the case of large-scale export deliveries. The engine of development of the world grain market is: price, competition, supply and demand. In this case, demand is characterized not so much from the standpoint of purchasing power, as taking into account the regulatory demand for grain. The continuity of the grain market can be ensured by strong competition, which is possible due to the large number of market participants who are unable to influence the market price.

At the present stage of management, most developed countries, in the context of food security and economic independence, develop their economic policies based on the support of grain stocks. Thus, applying elements of the policy of protectionism, the government, first of all, cares about the protection of domestic producers. Leading grain-exporting countries use economic mechanisms to regulate production as a means of state support.

Modern state levers of influence on the formation and development of agriculture in the highly developed countries of the world are formed from two elements - institutional and instrumental. The former are disclosed through the activities of public authorities, and the latter are expressed in regulations referred to by regulatory authorities in the course of their work.

Key words: world grain market, domestic grain market, agriculture, grain crops, sown area, grain export.

\section{Зелинская О.Н., Иванишев В.}

\section{ОРГАНИЗАЦИОННО-ЭКОНОМИЧЕСКИЕ ОСНОВЫ ФУНКЦИОНИРОВАНИЯ МИРОВОГО РЫНКА ЗЕРНА}

Сегодня в современной научной литературе присутствует ряд исследовательских работ, связанных с особенностями формирования и 
Економічні науки: збірник наукових праџь Луцького національного технічного університету. Серія “Регіональна економіка". Випуск 18 (71). Редкол.: відп. ред. д.е.н., професор Л.Л. Ковальська. Луиьк: ІВВ Луиького НТУ, 2021. 278 с.

функционирования мирового рынка зерна. Рынок зерна играет важную роль в обеспечении мировой продовольственной безопасности. В связи с этим, вопросы анализа и системного концептуального осмысления организационноэкономических основ и перспектив развития мирового рынка зерновых на современном этапе развития глобальной экономики являются разнородными по своей теоретико-методологической основой: в научно-исследовательском и экспертном сообществе существуют принципиально согласованы теоретические и практические различия в подходах, что обусловливает необходимость в аргументации целей и задач данного исследования.

Ключевые слова: мировой рынок зерна, отечественный рынок зерна, сельское хозяйство, зерновые культуры, посевная площадь, экспорт зерна.

Постановка проблеми у загальному вигляді і її зв'язок 3 важливими науковими та практичними завданнями. Характерною особливістю розвитку світового продовольчого ринку є збільшення обсягів міжнародної торгівлі зерновими, зокрема через зростання його попиту та пропозиції. Це, в свою чергу, $\epsilon$ значним потенціалом для розвитку вітчизняного аграрного експорту, однак створює певні ризики через мінливість світових цін на зерно.

Розвиток вітчизняного зернового ринку значно залежить від тенденцій розвитку світового ринку зерна. В сучасних умовах господарювання виробництво та експорт зернових здебільшого зосереджено в розвинених країнах світу, які в значній мірі можуть впливати на його розвиток. Останніми роками Україна доєдналася до числа ключових гравців на даному ринку.

Аналіз останніх досліджень, у яких започатковано вирішення проблеми. Вцілому питання функціонування та перспективного розвитку світового ринку зерна завжди були актуальними серед економічних досліджень. Проблемам дослідження основ функціонування та розвитку світового ринку зернових приділена велика кількість наукових праць вченихекономістів та експертів-практиків. Фундаментальні дослідження $з$ даної тематики подані у працях Кваші C.M., Камінського I.В., Кузнецової І., Лупенка Ю.О., Шпичака О.М., Месель-Веселяка В.Я., що вивчаючи світові ринки зернових культур проводять експетну оцінку. 
Економічні науки: збірник наукових праџь Луцького національного технічного університету. Серія “Регіональна економіка". Випуск 18 (71). Редкол.: відп. ред. д.е.н., професор Л.Л. Ковальська. Луцьк: ІВВ Луиького НТУ, 2021. 278 с.

Однак, при наявності грунтовних наукових напрацювань за зазначеною тематикою, вивчення засад розвитку світової торгівлі зерном та участі в ній України залишається актуальним.

Цілю даної статті $є$ вивчення організаційно-економічних основ формування та функціонування світового ринку зернових культур.

Виклад основного матеріалу дослідження 3 повним обгрунтуванням отриманих наукових результатів. Сьогодні світовий ринок зернових продуктів залишається одним 3 ключових та стратегічних векторів вітчизняного експорту аграрної продукції. Будь-які зміни чи тенденції на даному ринку чинять безпосередній вплив на стан та динаміку аграрного експорту України, як країни що є одним 3 ключових гравців ринку.

В сучасних умовах господарювання даний ринок знаходиться в об'єктиві постійного моніторингу. Результати даних досліджень містять цінну інформацію щодо ринкової кон'юнктури, яка необхідна для розробки та прийняття управлінських рішень.

Ринок зерна - це відкрита організаційно-господарська система, за допомогою якої господарюючі суб'єкти реалізують власні економічні інтереси в сфері експорту-імпорту зернових продуктів. Досліджуваний ринок наділений такими характерними рисами: цілісність, ієрархічність та інтегрованість [1].

Досліджуючи організаційно-економічні засади функціонування світового ринку важливо вивчити закони та закономірності, оскільки стан розвитку даного ринку безпосередньо впливає на розвиток споріднених виробництв та галузей економіки. Крім цього варто нагадати, що зерно $\epsilon$ ключовим елементом продовольчої безпеки будь якої держави. Саме цим пояснюється надмірна зацікавленість країн в їх участі на даному ринку.

Функціонування світового ринку зерна можна звести до наступних цілей:

- забезпечення населення товаром першої необхідності; 
Економічні науки: збірник наукових праџь Луцького національного технічного університету. Серія “Регіональна економіка". Випуск 18 (71). Редкол.: відп. ред. д.е.н., професор Л.Л. Ковальська. Луиьк: ІВВ Луцького НТУ, 2021. 278 с.

- забезпечення зерновими споріднені галузі;

- розробка логістичних напрямів від виробників до кінцевих споживачів;

- проведення дерзагтівельних робіт та здійснення товарних інервенцій на ринку зерна;

- вирощування експортних партій зерна [2].

В процесі розвитку економічної взаємодії між суб' єктами світового ринку зерна сформувалися так звані інтеграційні моделі виробників та споживачів зерна, які уособлюють юридично незалежні компанії та різного роду некомерційні об'єднання. Такі взаємовідносини формуються внаслідок спільної виробничої і маркетингової діяльності, взоєморозрахунків тощо [3].

Таким чином, світовий ринок зерна $є$ важливою категорією, що вдало поєднує системи соціально-правових та економічних відносин між учасниками зернового ринку. Базові принципи ринку зерна подано на рисунку 1.

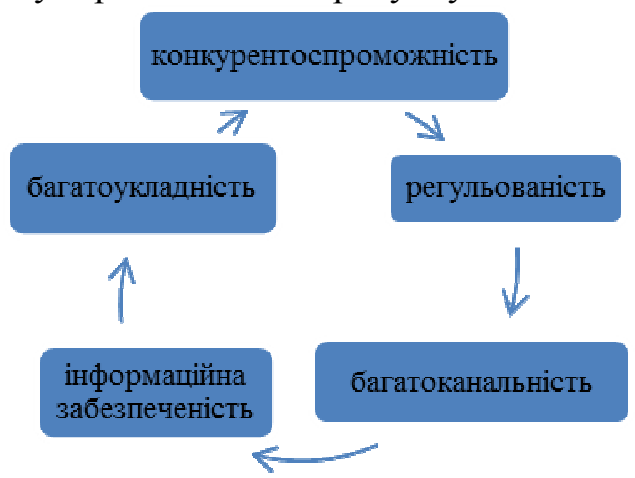

Рис. 1. Принципи, що діють на світовому ринку зерна

В процесі вивчення особливостей засад функціонування світового ринку зернових, необхідно відмітити що зерно, будучи гарантом продовольчої безпеки є також джерелом багатства держави. Крім цього зерно являється товаром як внутрішнього та к і зовнішнього ринків, а ринок зерна при цьому - один 3 найбільш досконалих та прогнозованих у світі [4]. 
Економічні науки: збірник наукових праџь Луцького національного технічного університету. Серія “Регіональна економіка". Випуск 18 (71). Редкол.: відп. ред. д.е.н., професор Л.Л. Ковальська. Луцьк: ІВВ Луиького НТУ, 2021. 278 с.

В основу організаційно-економічних засад функціонування світового ринку зернових покладено наступні характеристики:

1. купівля/продаж стратегічного товару;

2. частина товару забезпечує внутрішньовиробниче споживання, решта - експортується;

3. пропозиція даного специфічного товару залежить від погодних факторів;

4. сезонність виробництва створює передумови для формування запасів;

5. гостра конкурентна боротьба між учасниками ринку;

6. попит знаходиться в прямій залежності від наявності переробних підприємств;

7. оскільки попит на хліб має нееластичний характер, то це породжує стійку тенденцію до зростання попиту на зерно.

Основними факторами, що здатні впливати на попит та пропозицію на ринку зерна - це цінова політика потенційних експортерів, ціни на внутрішньому ринку, перехідні запаси, здатність держави здійснювати товарні інтервенції, цінова політика країн-імпортерів [5].

Враховуючи той факт, що зерно, як товар не $\epsilon$ дороговартісним, тому рентабельність його експортування буде дещо вищою у випадку масштабних експортних поставок. Рушієм розвитку світового ринку зернових є: ціна, конкуренція, попит та пропозиція. При цьому попит характеризується не стільки з позиції купівельної спроможності, скільки враховуючи нормативну потребу в зернових. Безперебійність ринку зерна здатна забезпечити потужна конкурентна боротьба, яка $\epsilon$ можливою через велику кількість учасників ринку, які не взмозі впливати на ринкову ціну.

На сучасному етапі господарювання, більшість розвинених країн, в контексті продовольчої безпеки та економічної незалежності розробляють свою економічну політику на основі підтримки запасів зернових. Так, застосовуючи елементи політики протекціонізму, влада, в першу чергу, дбає про захист вітчизняного товаровиробника. 
Економічні науки: збірник наукових праџь Луцького національного технічного університету. Серія “Регіональна економіка". Випуск 18 (71). Редкол.: відп. ред. д.е.н., професор Л.Л. Ковальська. Луцьк: ІВВ Луиького НТУ, 2021. 278 с.

Провідні країни-експортери зернових використовують економічні механізми регулювання виробництва як засоби державної підтримки [6].

Сучасні державні важелі впливу на становлення та розвиток сільського господарства в досить розвинених державах світу формуються 3 двох елементів - інституційних та інструментальних. Перші розкриваються через діяльність органів влади, а другі знаходять своє вираження в постановах, на які посилаються під час своєї роботи регулюючі органи.

Висновки. Проведене дослідження показує, що український зерновий ринок глибокоінтегрований у світовий торговельний простір, тобто вже спроможний як впливати на кон'юнктуру світового ринку зернових, так і знаходитися під іiі впливом.

Також для використання експортного потенціалу необхідно грунтовно вивчати зарубіжний досвід регулювання діяльності ринку зерна, але обов'язково 3 врахуванням національних, ментальних та економічних особливостей.

\section{Список бібліографічного опису}

1. Верховцев А.А. Теоретический аспект развития рынка зерна. Научный альманах. 2018. №11-1 (49). С.32-35

2. Жанабаева Ж.К. Рынок зерна и его значение для развития национальной экономики. Новости науки в АПК. 2018. № 2-2 (11). С. 254-257

3. Жидков С.А. Состояние и перспективы развития мирового рынка продовольственного зерна. Вестник Мичуринского государственного аграрного университета. 2019. №1. С. 154-156

4. URL: http://magazine.faaf.org.ua/suchasniy-stan-ta-osoblivosti-rinkivzerna-v-ukraini-ta-kanadi.html

5. Kyrylenko I.H., Ivchenko V.Ye., Demianchuk V.V. Main trends in the development of the world food market and production in Ukraine. Международный научно- производственный журнал «Экономика АПК». 2018. № 9(287). C. 34-45.

6. Суренкова В.А. Зарубежный опыт производства зерна. Colloquiumjournal. 2019. №16-9 (40). C. 19-21.

\section{References}

1. Verkhovtsev A.A. Teoretycheskyi aspekt razvytyia ronka zerna. Nauchnыi almanakh. 2018. №11-1 (49). S.32-35

2. Zhanabaeva Zh.K. Rыnok zerna y eho znachenye dlia razvytyia natsyonalnoi эkonomyky. Novosty nauky v APK. 2018. № 2-2 (11). S. 254-257 
Економічні науки: збірник наукових прачь Луиького національного технічного університету. Серія “Регіональна економіка". Випуск 18 (71). Редкол.: відп. ред. д.е.н., професор Л.Л. Ковальська. Луцьк: ІВВ Луиького НТУ, 2021. 278 с.

3. Zhydkov S.A. Sostoianye y perspektyvы razvytyia myrovoho runka prodovolstvennoho zerna. Vestnyk Mychurynskoho hosudarstvennoho ahrarnoho unyversyteta. 2019. №1. S. 154-156

4. URL: http://magazine.faaf.org.ua/suchasniy-stan-ta-osoblivosti-rinkivzerna-v-ukraini-ta-kanadi.html

5. Kyrylenko I.H., Ivchenko V.Ye., Demianchuk V.V. Main trends in the development of the world food market and production in Ukraine. Mezhdunarodnыi nauchno- proyzvodstvennыi zhurnal «Эkonomyka APK». 2018. № 9(287). S. 34-45.

6. Surenkova V.A. Zarubezhnыі орыt proyzvodstva zerna. Colloquiumjournal. 2019. №16-9 (40). S. 19-21.

DOI: https://doi.org/10.36910/2707-6296-2021-18(71)-6

УДК 339.176.004

Зубко Т.Л., к.е.н., доцент

Київський національний

торговельно-економічний

університет

\section{ІНСТРУМЕНТИ ІННОВАЦІЙНОГО РОЗВИТКУ ТОРГОВЕЛЬНОГО ПІДПРИЄМСТВА}

Торгівля розвивається швидкими темпами як у світі, так і в Україні, що пов 'язано не тільки з інвестиціями, але й з інноваціями. Тому вивчення та узагальнення досвіду їх застосування $\epsilon$ актуальним. У статті розглянуто теоретичні положення та практичний інструментарій залучення інновацій на торговельних підприємствах. Розглянуто види інновацій та відповідні їм стратегії. В статті також досліджено особливості інноваційної діяльності торгівельних підприємств. Удосконалено класифікацію базових інноваційних стратегій, які формуються залежно від положення організації на ринку та значущості інноваційного потенціалу.

Ключові слова: інноваційний розвиток, інструменти, торгівля, підприємства, євроінтеграція.

Zubko T.

\section{TOOLS OF INNOVATIVE DEVELOPMENT OF A TRADE ENTERPRISE}

Globalization processes in the world have stimulated the development of international trade, and accordingly, this area needs to find and justify ways to 